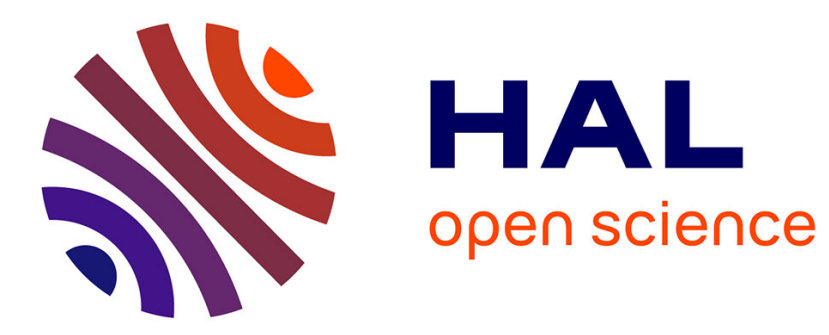

\title{
The Demand of Part-time in European Companies: A Multilevel Modeling Approach
}

Dominique Anxo, Shakir Hussain, Ghazi Shukur

\section{To cite this version:}

Dominique Anxo, Shakir Hussain, Ghazi Shukur. The Demand of Part-time in European Companies: A Multilevel Modeling Approach. Applied Economics, 2011, pp.1. 10.1080/00036846.2010.534075 . hal-00662388

\section{HAL Id: hal-00662388 \\ https://hal.science/hal-00662388}

Submitted on 24 Jan 2012

HAL is a multi-disciplinary open access archive for the deposit and dissemination of scientific research documents, whether they are published or not. The documents may come from teaching and research institutions in France or abroad, or from public or private research centers.
L'archive ouverte pluridisciplinaire HAL, est destinée au dépôt et à la diffusion de documents scientifiques de niveau recherche, publiés ou non, émanant des établissements d'enseignement et de recherche français ou étrangers, des laboratoires publics ou privés. 


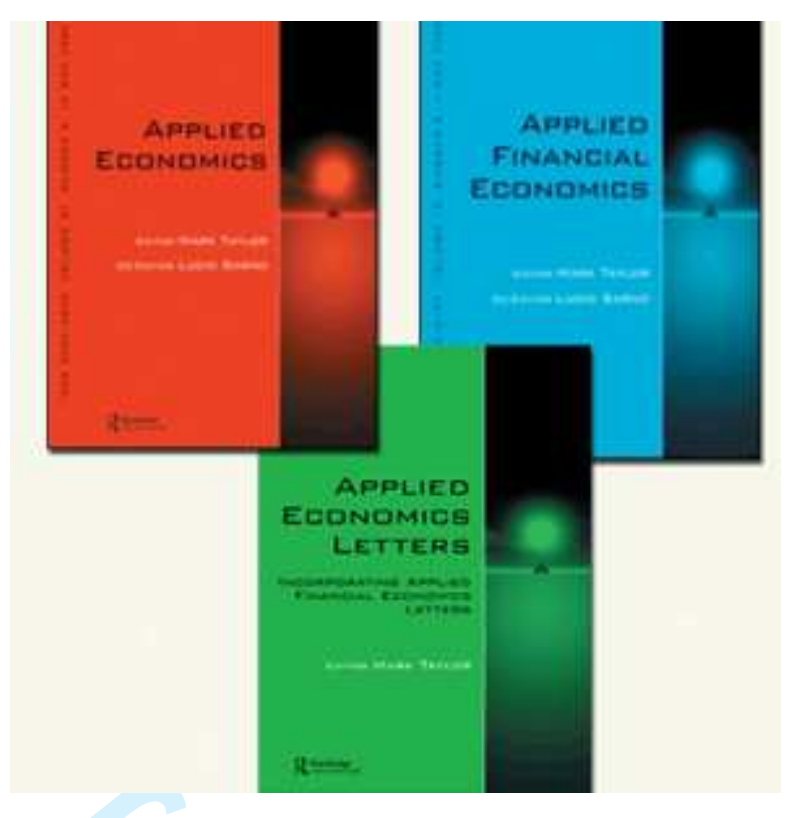

\section{The Demand of Part-time in European Companies: A Multilevel Modeling Approach}

\begin{tabular}{|r|l|}
\hline Journal: & Applied Economics \\
\hline Manuscript ID: & APE-2009-0041.R1 \\
\hline Journal Selection: & Applied Economics \\
\hline Author: & 08-Oct-2009 \\
\hline Complete List of Authors: & $\begin{array}{l}\text { Anxo, Dominique; Växjö University, Economics and Statistics } \\
\text { Hussain, Shakir; University of Birmingham, Division of Public } \\
\text { Health, School of Medicine } \\
\text { Shukur, Ghazi; Växjö University and Jönköping University, } \\
\text { Economics and Statistics }\end{array}$ \\
\hline JEL Code: & $\begin{array}{l}\text { J29 - Other < J2 - Time Allocation, Work Behavior, and } \\
\text { Employment Determination/Creation < J - Labor and Demographic } \\
\text { Economics, J21 - Labor Force and Employment, Size, and Structure } \\
<\text { J2 - Time Allocation, Work Behavior, and Employment } \\
\text { Determination/Creation < J - Labor and Demographic Economics, } \\
\text { C11 - Bayesian Analysis < C1 - Econometric and Statistical } \\
\text { Methods: General < C - Mathematical and Quantitative Methods, } \\
\text { C40 - General < C4 - Econometric and Statistical Methods: Special } \\
\text { Topics < C - Mathematical and Quantitative Methods }\end{array}$ \\
\hline
\end{tabular}




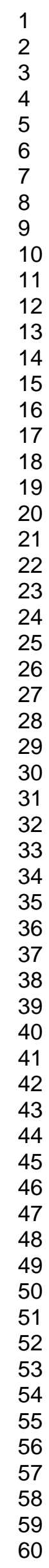

\section{ScholarONE"}




\section{The Demand of Part-time in European Companies: A Multilevel Modeling Approach}

\section{Introduction}

Over the last two decades, the incidence of part-time has significantly increased in most European Union (EU) countries. Working time arrangements and work-life balance issues have been the focus of a series of cross-national European surveys and empirical studies. These comparative studies have pointed to large differences in the development and extent of part-time employment creating marked cross-country differences in the duration and distribution of working time (See Anxo and O'Reilly, 2000). To explain such differences, the focus has been mainly on labor supply considerations and institutional arrangements pertaining to working-time. These empirical studies, predominantly based on data from surveys of individuals, have clearly shown that part-time employment remains largely dominated by women and concentrated in the service sector. In 2006 , more than $30 \%$ of European women worked part time (Eurostat, 2007) and for many of them this «atypical» working time arrangements constitutes a way of conciliating work with family commitments. Even though a significant part of the expansion of part-time work might be ascribed to the feminization of the labor force and to changing individual preferences regarding working time arrangements over the life course, the growth of part time employment appears also to be related to companies' search for increasing organizational flexibility and productive efficiency, in a context of increasing international competition.

In contrast to previous studies, focusing on the supply side of the labor market, the originality of our research is to investigate the demand-side of part-time work and to examine the extent to which European companies use part-time work. The main objective of the present paper is therefore to explore the factors affecting the distribution of working time at the establishment level. More explicitly, our main concern is to assess the impact of firms' characteristics (such 
as productive constraints, the age, gender and skill composition of the work force, work organization etc) and countries' institutional arrangements on the use and intensity of parttime jobs at the establishment level. Based on a large sample of European firms (more than 21000 establishments) operating in 21 EU Member States and providing a rich and unique set of information on companies' characteristics and working time distribution we estimate the impact of firms' characteristics on the incidence of part-time work by using a multilevel multinomial modeling in a Bayesian environment. In contrast to a previous attempt (see Anxo et al., 2007), using standard multinomial logit, our approach has the advantage to better discriminate the impact of institutional environmental factors (country specific features) from industry and firm specific factors.

This paper is structured in the following way. After a description of the data set used (Section 1) and the presentation of some descriptive statistics regarding the cross country disparities in the use of part-time work at the firm level (Section 2) some theoretical developments are provided concerning employers' motives and rationales for introducing part-time work (Section 3). The next sections provide a description of the estimation procedure (Section 4) and an analysis of our main results (Section 5). Finally the last section includes some conclusive remarks and developments concerning future possible extension.

\section{Description of the data set}

In order to obtain more in depth information on working time patterns in European companies, the European Foundation for the Improvement of Living and Working Conditions launched in 2004, a large-scale sample establishment survey in 21 European countries: the 15 'old' Member States of the European Union (EU15) and six of the new Member States (the Czech Republic, Cyprus, Hungary, Latvia, Poland and Slovenia). In more than 21,000 
establishments personnel managers were interviewed about working time arrangements ${ }^{1}$ and work-life balance issues in their companies. Data of the European Establishment Survey on Working Time and Work-Life Balance (ESWT) are representative for all companies with 10 or more employees in the above-mentioned countries. The survey covers private and public establishments from practically all sectors of activity ${ }^{2}$. The sample design provided for a control of the representative distribution of interviews among the two main sectors 'Industries' (NACE C - F) and 'Services' (NACE G - O). Interviews for the survey were carried out via telephone in the autumn of 2004 (EU15) and the spring of 2005 (six new Member States) $)^{3}$. In total, 21,031 personnel managers were interviewed and 5,232 employee representatives from the same establishments. (More details on survey methodology can be found in Riedman et al., 2006).

The ESWT is one of the very few cross-national surveys exploring working time arrangements and work-life balance issues from the perspective of establishments or companies. The ESWT makes it possible to explore the extent to which companies use part-

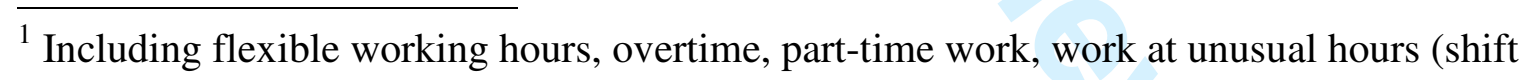
work, night work, and weekend work), parental leave and phased and early retirement. A common feature of all these time arrangements is that they deviate from the standard working time regime (i.e. full time hours, Monday to Friday) with respect to duration, distribution or timing of working time.

2 The only sectors excluded are 'Agriculture', 'Forestry', 'Private households' and 'Extraterritorial organizations'. In these sectors the number of establishments with 10 or more employees is negligible in the countries surveyed.

${ }^{3}$ TNS infratest Sozialforshung, Munich coordinated the fieldwork.
} 


\section{Incidence of part-time work in European companies ${ }^{5}$}

Part-time work has become a widespread work arrangement among European companies. Almost two-thirds of establishments covered by the ESWT have some experience of part-time work. Around $40 \%$ establishments exhibits a low incidence of this type of working time arrangement (with less than $20 \%$ of part-time workers among the workforce) while $24 \%$ displays a high incidence with more than $20 \%$ of their work force on part-time basis.

As shown in Anxo et al. (2007), there are large cross-country differences in the extent of parttime work across European firms. The Netherlands and Scandinavian countries (Denmark and Sweden) display a much higher share of establishments with part-time employees compared to southern and eastern European countries. To illustrate: In the Netherlands, $89 \%$ of establishments have part-time employees in their workforce, whereas this applies to only $13 \%$ of establishments in Portugal. It is also interesting to note that countries with a high incidence

\footnotetext{
${ }^{4}$ In the ESWT part-time employment is defined as 'less than the usual full-time hours'.

${ }^{5}$ This descriptive part relies heavily on a report commissioned by the European Foundation for the Improvement of Working and Living Conditions see Anxo et al. (2007).
} 
of part-time work have also a larger proportion of 'high-incidence companies' (20\% or more of the workforce are part-time workers).

These national differences in the incidence of part-time at the establishment level might be ascribed to a 'country specific effect', highlighting the influence of national discrepancies in the legal and institutional framework as well as societal preferences regarding the distribution of working time. However, part of this variation might be due to compositional differences in the industrial structure across countries, given that part-time work is more likely to be used in certain types of establishment according to characteristics such as economic activity, company size or female presence in the workforce.

Beyond this country effect, there are also significant variations across establishments in the incidence of part-time work. Establishments are more likely to have part-time workers if they are operating in the service sector (in particular, the public sector), in large establishments, and have a high proportion of women in the workforce. To illustrate: almost $70 \%$ of establishments in the service sector report that they employ part-time workers, compared with around $50 \%$ in manufacturing industry. Establishments with a high rate of part-time employment are predominantly concentrated in the following sectors: health and social work; education; other community, social and personal services; hotels and restaurants. As far as the firms' size is concerned, although nearly half of small establishments (with less than 50 employees) have experience of part-time work, the corresponding figure for medium-sized (with 50-199 employees) and large establishments (with 500 or more employees) is about $80 \%$. It appears also that, establishments with a high incidence of part-time work (more than $20 \%$ ) are predominantly large establishments in the services sector. Given that part-time work is dominated by women, it is not surprising that the incidence of part-time work 
increases with the share of women in the workforce: part-time work is found in $43 \%$ of establishments with few female employees, compared with $80 \%$ of establishments with a high proportion of women in the workforce. As also revealed by the ESWT survey, the most common groups of employees used for part-time work were mothers with pre-school or school-age children. Establishments are also more likely to have a large proportion of parttime workers if they employ a high proportion of young (aged less than 30 years) or older (aged 50 years or more) employees. On the other hand, there is no clear relationship between the level of skilled jobs and the usage of part-time work.

There are also reasons to believe that the incidence of part-time work is related to variations in the workload. A high incidence of part-time work appears to be more frequent in establishments that have to cope with major and mostly foreseeable short term or seasonal variations of the workload. In order to meet the demands of establishments, part-time work may also be used in conjunction with other types of labor flexibility. Part-time work may therefore interact with other working time arrangement (shift work, night work, weekend work) or contractual forms (short term contracts, temporary agency workers or freelancers) as either a complement or a substitute in providing flexibility. As shown in Anxo et al. (2007), companies that make some use of limited duration contracts are less prone to operating only with full time employees. A high usage of part-time work is also connected with a high proportion of employees working at the weekend or at night in establishments.

\section{Employers' motives and rationales for introducing part-time work}

Previous theoretical and empirical economic research (Owen, 1978, Montgomery, 1988, Friesen, 1996) has analyzed the main motives for employers to use part-time work. In a seminal work, Oi (1962) introduced the concept of quasi-fixed labor costs - costs that firms 
pay on a per-worker basis irrespective of the hours worked by the employee. Hence in addition to hourly wages, firms usually bear per-employee (quasi-fixed) costs of labor, such as fringe benefits, recruitment and training costs. High quasi-fixed labor costs might, ceteris paribus, decrease the relative attractiveness of part-time workers and the cost of recruiting and training might be a significant impediment to the hiring of part-timers. The distribution of quasi-fixed cost is related to various characteristics of the firm. Because firms tend to invest less in training for low-skill workers than those with high-skill positions, we may therefore expect that companies with a higher share of low-skilled jobs will find part-timers relatively more attractive. The size of the firm may also influence quasi-fixed cost because large firms may experience lower supervisory and administrative costs per worker, due to developed human resource department. Smaller firms, therefore, can be expected to have lower proportion of part-timers in the work force. By the same token, we may also expect that parttimers are relatively less attractive in highly knowledge and capital intensive industries. Firms may be motivated to hire part-time workers partly because such workers can provide them with more flexibility in adjusting their labor force in front of a foreseen short term or seasonal variations of the workload.

This kind of "optimal staffing" for regular peaks in workload is principally aimed at minimizing labor cost and at adjusting the work force to predictable variation in activity level. Another motive is to secure organizational flexibility and reduce labor cost through introducing low paid, low skilled jobs to cover extended operating, opening or variable hours; In other words, there is reason to believe that some firms recruit part-time workers as a relative inexpensive way of gaining some organizational flexibility. Another rationale is to meet the needs and wishes of employees regarding reduced working time, in order to attract and keep specific segment of the labor force and/or to comply with the application of statutory 


\section{Methodological considerations and estimation procedure.}

As shown previously, the incidence of part-time employment at the establishment level varies widely across European countries. A large part of these variations might be ascribed to differences in the legal and institutional framework and/or societal preferences. However, part of the observed discrepancy may also be ascribed to compositional differences in the industrial structure across various countries. Given that part-time work, as stressed previously, is more likely to be used in certain types of establishment according to characteristics such as economic sector, company size or female presence in the workforce, we turn now to multilevel multinomial techniques in order to better discriminate between "country specific factor' versus 'industrial structure' and companies characteristics.

As a starting point we assume that a firm decides upon its working time distribution by choosing between three main working time regimes: only full time workers, a low share of part-time workers (less than $20 \%$ of employees) and a high incidence of part-time workers (20\% employees or more). The choice of the threshold/cutting point for the incidence of parttimers has been essentially driven by data consideration and modeling procedure ${ }^{6}$.

\footnotetext{
${ }^{6}$ As above mentioned the distribution of firms according to working time is following: $46 \%$ of the surveyed establishments do not make use of part-time workers, $40 \%$ of establishment displays a low incidence of part-time work (less than $20 \%$ of the work force) and $24 \%$ of establishments have a high incidence of workers working part-time (20\% of the work force or more). Furthermore, the multilevel multinomial model using these cutting points has shown to
} 
As previously mentioned, the main objective of this paper is twofold: firstly to explore the factors affecting the distribution of working time at the establishment level, secondly to explain the observed variation in the use of part-time work by using a multilevel perspective, i.e. by applying a multilevel multinomial logistic regression to our data. The units in such a system lie at two to three different levels of a hierarchy. Disregarding this hierarchy and using standard estimation methods (such as standards multinomial logit or probit) is not appropriate in this case and will give biased and misleading results.

A typical suitable multilevel model (see Goldstein, 1995) of this system would assign firms to level one, groups of industries to level two and countries to level three. Units at level one are recognized as being grouped, or nested, within units at the next higher level. In our case we have the establishment nested within industries and industries nested within countries. From this point of view of our model what matters is how this hierarchical structure affects the measurements of interest. Thus when modeling the distribution of working time across European establishments, it is expected that this distribution varies from one industry to another and from one country to another and hence generates two covariance matrices. The multilevel approach we use in this paper helps us investigate many important issues related to the study. Patterns of variability, in particular nested form of variability, are studied with respect to different variables of interest. The fixed effect and the random effects are parts of the outcome of the multilevel model that helps us decide the significance and direction of each effect.

Very often it makes sense to use probability models to represent the variability within and between groups, i.e. to perceive the unexplained variation within groups and the unexplained

fit the data better than the more aggregate binomial model (including only full time and part time) and a number of other multinomial models with different cutting points. 
variation between groups as random variability. For our study, for example, this means that not only unexplained variation between establishments, but also unexplained variation between sectors or countries are regarded as random variability. This can be expressed by statistical model with so-called random coefficients, and the hierarchical model is such a random coefficient model for multilevel data (see the following equation (1)).

Now, let $Y_{i j k}$ be the categorical response for a company $i$ in sector $j$ and country $k$. Where $Y_{i j k}$ may range between 0 and $\mathrm{t}$. In our case, $Y_{i j k}=0$ if one establishment is operating with only full time workers, $Y_{i j k}=1$ if one company has a low incidence of part time workers, and lastly $Y_{i j k}=2$ for a company choosing a high incidence of part time workers. Hence, with these three possible outcomes (full time, low incidence of part-time and high incidence of parttime), we will have two equations representing the change in odds of being in a specific group rather than in the reference category. In the present paper our reference category is the establishments operating only with full time workers. In addition to the fixed effect, we are also interested in the covariance matrices of the 2 multivariate outcomes at sector and country levels, respectively.

The three level random intercept multinomial logistic regression model can be written as:

$$
\log \left(\frac{p_{i j k}^{(s)}}{p_{i j k}^{(t)}}\right)=B_{0}^{(s)}+B^{(s)} X_{i j k}+u_{j k}^{(s)}+v_{k}^{(s)}
$$

The probability of being in category $s(s=1,2)^{7}$ in sector $j$ and country $k$ is $p_{i j k}^{s}$, and the probability of being in category 0 , the reference category, is $1-\sum_{s} p_{i j k}^{s}$.

$B_{0}^{s}$ is the logarithm of the ratio of the overall probability of a firm being in category $s$ to the reference category (only full time workers). A positive estimate of $B_{0}^{s}$ suggests a larger

\footnotetext{
${ }^{7}$ i.e. low incidence of part-time workers $(s=1)$ and high incidence of part-time workers $(s=2)$
} 
probability of being in category 1 or 2 than in the reference category. The vector of explanatory variables $\mathbf{X}_{i j k}$, may include any number of predictors that we like to investigate. In our case we use the following covariates that are relevant in determining the choice of companies' working time distribution: the establishment size, age, gender and skill composition of the work force, type of work organization (night, shift and week-end work, incidence of short term contracts and overtime, absenteeism), the short term and seasonal variation of the workload. Note that all the continuous fixed effect variables included in the analysis have been standardized by taking their deviations from the means and then divided by their own standard errors. The variation for these variables from zero to one is hence equivalent to one standard deviation (see Table A1 in the appendix). This should be taken into account when interpreting the results in Table 1 in the next section.

The term $u_{j k}^{(s)}$ in equation (1) is a sector-level random effect in country $k$, while $v_{k}^{(s)}$ is a country-level random effect. Both $u_{j k}^{(s)}$ and $v_{k}^{(s)}$ are assumed to be normally distributed with mean 0 and variance $\sigma_{u}^{2(s)}$ and $\sigma_{v}^{2(s)}$. The third level (country) variance $\sigma_{v}^{2(s)}$ will add extra variance component to the total variance of the data structure. The random effects are outcome-specific, as indicated by the $s$ superscript, because different unobserved sector-level and country-level factors may affect each outcome. The variance structure at the countrylevel (level 3) is given by:

$$
\operatorname{Var}\left(v_{k}^{(1)}+v_{k}^{(2)}\right)=\sigma_{v}^{2(1)}+2 \sigma_{v}^{(1,2)}+\sigma_{v}^{2(2)} .
$$

In the same manner, the variance structure at the sector-level (level 2) can be written as follows:

$$
\operatorname{Var}\left(u_{j k}^{(1)}+u_{j k}^{(2)}\right)=\sigma_{u}^{2(1)}+2 \sigma_{u}^{(1,2)}+\sigma_{u}^{2(2)}
$$


Moreover, the random effect may be correlated across outcomes: $\operatorname{Cov}\left(u_{j}^{(s)}, u_{j}^{(r)}\right)=\sigma_{u}^{(s, r)}$ and $\operatorname{Cov}\left(v_{k}^{(s)}, v_{k}^{(r)}\right)=\sigma_{v}^{(r, s)}, s \neq r$. Correlated random effects would arise, for example, if there were unobserved country-level factors which affect the choice of more than one type of working time category. For example, a positive estimate of the covariance between categories 1 (low incidence of part-timers) and 2 (high incidence of part-timers) of the country or sector $\log$ ratios implies that a country or a sector with a high share of firms with a low incidence of part-time workers tends to have a higher proportion establishments with a high incidence of part-time workers and conversely with a negative estimate of the covariance.

The Intra-class Correlation Coefficient $(\mathrm{ICC})^{8}$ of the s contrast for the country level and country and sector level can respectively be written as:

$$
\mathrm{ICC}=\frac{\sigma_{v}^{2(s)}}{\sigma_{v}^{2(s)}+\sigma_{u}^{2(s)}+\pi^{2} / 3} \text { and } \frac{\sigma_{v}^{2(s)}+\sigma_{u}^{2(s)}}{\sigma_{v}^{2(s)}+\sigma_{u}^{2(s)}+\pi^{2} / 3},
$$

Where $\frac{\pi^{2}}{3}$ is approximately equal to 3.29 . A large ICC indicates the existence of the hierarchical structure in the data and that a multilevel estimation is needed, while a low value of ICC indicates that the data does not pronounce clear clustering structure.

The separate intercept and the parameters associated with the included covariates, $X_{\mathrm{ijk}}$, in equation (1) can be estimated, by Markov Chain Monte Carlo (MCMC) method for each contrast. The posterior sampling in this study has been conducted using Gibbs sampler with 5000 replications.

The exponential parameters $B^{(s)}$ in model (1) are then interpreted as one unit changes in the standard deviation of the X:s on the log odds of being in category s (Low or high incidence of

\footnotetext{
${ }^{8}$ The Intra-class Correlation Coefficient gives the proportion of variance attributable to between group differences (in our case countries or sectors within countries).
} 
part-timers) rather than category $\mathrm{t}$ (full time workers only). The estimation has been done using the statistical program packages; Mlwin version 2.0 and S+ version 8.01.

\section{Results}

Table 1 summarizes the MCMC multilevel multinomial logistic regression results of the estimated parameters together with their standard errors from the fixed effects.

The first column displays the estimated coefficients for contrast two to one (i.e. low incidence of part-timers relative to only full timers), while in column two we have the results for the log odds ratio for contrast three to one (high incidence relative to only full timers). Column 3 and 4 report the impact of the covariates on the log odds ratio for the two contrasts. Table A2 in the appendix reports the random effect part, i.e. the variance-covariance matrix at the level two (sectors) and level three (countries).

\section{Table 1 here}

The negative intercept implies that the two categories are less likely to occur than the reference category (only full time workers), and that the probability of the second contrast (high incidence of part-time workers) is several times less than that of the first contrast. In other words, the likelihood that, a firm uses, ceteris paribus, a large share of part-time workers, relative to only using full time workers, is much lower, than to use a lower share of part-timers which is furthermore not statistically significant.

When looking at the fixed effect variables, we can see that the estimated coefficients in the first column (i.e. the $\log$ of the odds ratio of contrast two to one) and the second column (i.e. the log of the odds ratio of contrast three to one) are almost all statistically significant at conventional level and have the expected sign. 
As expected the gender composition of the work force does affect the distribution of working time at the firm level. The proportion of women in the work force has a positive significant effect on the odds ratio in both cases, with almost four time larger effect for the high incidence firms. This indicates that a high intensity of part-time workers is more widespread in firms with a high share of female employees. A variation with one standard deviation in the proportion of female workers increases the likelihood that the firm operates with a low incidence of part-timers by respectively 3,3 percentage points (or 7\%) and by 4,4 percentage points (or 78\%) for firms operating with a high incidence of part-timers (See Table A4 in the appendix). The age composition of the work force also has a positive impact on part-time intensity, to have a high share of young or older workers increases the probability that the firm use part-timers. As shown by table A4 in the appendix, the impact of the age composition of the work force (the marginal effect) is however significantly higher for the 
high incidence case, an increase with one standard deviation in the share of older (young) workers increases the likelihood for a firm to have a high incidence of part-timers by almost $10 \%(7 \%)$. In other words, firms operating with a high incidence of part-timers display a less even age distribution of their work force.

As shown by our results, the incidence of part-time at the establishment level is positively correlated with the use of short term contracts. Worth also noticing is that this correlation is stronger in the case of low incidence firms. An increase by one standard deviation in the incidence of short term contracts increases the likelihood that the firm use a low (high) incidence of part-time workers by $18 \%$ (respective $11 \%$ ). This result seems to indicate some form of complementarity between external flexibility and internal working time flexibility.

Worth also noticing is that the skill level of the work force is not significant in the case of low incidence of part-timers. On the other hand, the higher the share of skilled workers the lower is the likelihood that the firm is using a high share of part-timers. An increase with one standard deviation in the proportion of skilled workers in the establishment decreases the probability that the establishment makes use of a high incidence of part-timers by $10 \%$.

As far as work organization is concerned, firms operating during week-ends are more prone to make use of part-timers. The effect is significantly positive in both case, but about four times larger for firms with a high incidence of part-time workers. Firms operating during week-ends are therefore less likely to only employ full-time workers and are more prone to display a large share of part-timers. As shown by column 3 and 4 of Table 1 the odds for a firm to have a low incidence of part-time compared to have only full time workers is 1,22 higher if the firm is producing during week end, and the odds for a firm to have a high incidence of parttimers is 2,3 higher. Looking at the marginal effect, we see (Table A4) that the quantitative impact is also important, for the low incidence the likelihood is increased by 4 percent and by 
44 percent for the high incidence case. Shift work also increases the likelihood to use parttimers, but shift work seems more prevalent in firms operating with a low incidence of parttimers. As far as night work is concerned we found a significant negative correlation in the case of firms with high incidence of part-timers. Ceteris paribus, firms operating at night are 8 percent less likely to have a high incidence of part-timers. The same is true for overtime. Firms with a high incidence of overtime have lower probability to have a high share of parttimers among their work force (- 13 percent, see Table A4)

As previously mentioned, the choice of employing part-timers may be affected by the variability and predictability of the company's demand over time. Part-timers may be used to cope with expected short-term (on a daily or weekly basis) or seasonal variations of the workload and we may expect that the use and intensity of part-timers will be positively correlated with foreseen variations of demand. Predictable seasonal variations of the workload are positively correlated with the probability that the firm makes use of a low incidence of part-timers, but not significant for high incidence firms. It is also interesting to note that the effect of short term variation of demand on a daily or weekly basis reduces the likelihood of using part-timers. So our result suggests that, ceteris paribus, European establishments do not use part-timers for coping with short term variations of the workload. On the other hand, we found a positive correlation between seasonal variations of the workload and the use of a low share of part-timers. Part-timers are therefore essentially used at the establishment level for coping with predictable seasonal variations but not short-term variation of the workload. On the other hand, as suggested by our results, a high rate of absenteeism increases the likelihood that the firm makes use of part-timers. Obviously, we cannot assess the direction of causality; either the rate of absenteeism is higher among firms using part-timers or that firms with a high 
rate of absenteeism are more prone to use part-timers in order to cope with the absenteeism of their employees.

Looking now at the random variability, the variances and covariances are all statistically significant as shown by Table A2 in the appendix. This suggests that the data exhibit clear clustering of firms nested within sectors and clear clustering of sectors nested within countries. Worth noticing also is that the variances at the country level are about two to three times larger than the variances at the sector level. In other words, the random variation between countries is larger than the random variation between sectors. One tentative explanation is that variation in the extent of part-time workers at the establishment level is determined more by country-specific features, such as societal and institutional factors, than by sector specific factors. If this tentative explanation is true, it means that the institutional set-up or the overall working time regime plays a stronger role than organizational or productive constraints related to sector specific factors. In other words, the observed country variation in part-time intensity is not primarily related to differences in industry structure/composition between countries but more by working time policy regimes and/or societal preferences. This interpretation is also reinforced by the analysis of the Intra-class Coefficient (ICC, see Table A3 in the appendix). As previously mentioned the Intra-class Correlation Coefficient gives the proportion of variance attributable to between group differences (in our case countries or sectors). As shown by the table, firstly, the ICC:s are quite large supporting the choice of our multilevel modeling for the data under consideration. Secondly, we see that the proportion of variance attributable to unexplained country factors is several times higher that those attributable to sectoral/industry factors. Worth also noticing is that both the variance and the ICC at the country level significantly increases with part-time intensity. 
The second interesting results is that, the countries' and sectors' random effects covariances are both positive (see Table A2 in the appendix). In other words, this result indicates that the sectors' or countries' random effects are not independent. It means that countries or sectors with low incidence of part time work also tend to have high incidence of part time work and conversely.

\section{Conclusive remarks}

The result of our estimation is well in accordance with theoretical considerations regarding the demand of part-time at the firm level. In particular, our results suggest that European establishments with a high incidence of female employees, an uneven age distribution, a high proportion of low skill workers and short term contracts as well as establishments operating during week-ends are more prone to use a large share of part-time workers. The second interesting results is that the variation in the extent of part-time workers at the establishment level is determined more by country-specific features, such as societal and institutional factors, than by industry specific factors. In other words, our results suggest that the institutional set-up or the overall working time regime plays a stronger role than organizational and/or productive constraints related to industry specific factors. Hence the observed variation in part-time intensity is not primarily related to differences in industry structure/composition between countries but more by working time policy regimes and/or societal preferences. Next step in our research of the determinants of part-time at the company level will be to select and include both macro variables at the country level and industry specific covariates in order to better enhance our understanding of the role of both the institutional set up and industry specific factors 


\section{Appendix: Tables}

Table A1 here

Table A2 here

Table A3 here

Table A4 here

\section{List of References}

Anxo, D. and O'Reilly J. (2000). “Working Time Regimes and Transitions in Comparative perspective" in Working Time Changes: Social Integration through Transitional Labour Market, (O’Reilly et al. eds.), Edward Elgar Publisher. 2000

Anxo, D., Fagan C., Letablier M-T., Perraudin C. and Smith M. (2007). Part-time Work in European Companies, European Foundation for the Improvement of Living and Working Conditions, Luxembourg: Office for Official Publications of the European Communities.

ESWT, (2004-2005). "Establishment Survey of Working Time and Work-Life Balance 20042005”, European Foundation for the Improvement of Living and Working Conditions, Luxembourg: Office for Official Publications of the European Communities.

Eurostat, 2007. Employment in Europe, Luxembourg: Office for Official Publications of the European Communities, Luxembourg..

Friesen, J. (1996). "The Dynamic Demand for Part-time and Full-time Labor", Economica, Vol. 64 pp 495-507. 
Goldstein, H. (1995). Multilevel Statistical models. $2^{\text {nd }}$ edition. London: Edward Arnold.

Montgomery, M. (1988). “On the Determinants of Employer Demand for Part-Time Workers, The Review of Economics and Statistics, Vol. 70, No. 1 (Feb., 1988), pp 112-17.

Oi, W.I. (1962). "Labor as a Quasi-Fixed Factor". The Journal of Political Economy, Vol. 70, No. 6, 538-555. Dec., 1962

Owen, J.D. (1978). "Why part-time workers tend to be in low wage jobs", Monthly Labor Review, 101 (6), 11-14.

Riedman, A., Bielenski, H., Szczurowska, T. and Wagner A. (2006). Working time and worklife balance in European companies, European Foundation for the Improvement of Living and Working Conditions, Luxembourg: Office for Official Publications of the European Communities. 
Table in the text: The Demand of Part-time in European Companies: A Multilevel Modeling Approach

Table 1: Results from the multilevel regression in two stages. Estimated parameters and the odds ratio exponential parameters.

\begin{tabular}{|c|c|c|c|c|}
\hline Fixed Effects & $\begin{array}{l}\text { Estimated } \\
\text { Parameters. } \\
\text { Low } \\
\text { incidence of } \\
\text { Part-timers }\end{array}$ & $\begin{array}{l}\text { Estimated } \\
\text { Parameters. } \\
\text { High incidence } \\
\text { of Part-timers }\end{array}$ & $\begin{array}{l}\text { Odds ratio } \\
\text { Exp }(\beta) . \text { Low } \\
\text { incidence of } \\
\text { Part-timers }\end{array}$ & $\begin{array}{l}\text { Odds ratio } \\
\text { Exp }(\beta) . \\
\text { High } \\
\text { incidence of } \\
\text { Part-timers }\end{array}$ \\
\hline $\begin{array}{l}\text { Intercept (grand } \\
\text { mean) }\end{array}$ & $\begin{array}{l}-0.044 \\
(0.140)\end{array}$ & $\begin{array}{l}-2.154^{*} \\
(0.430)\end{array}$ & & \\
\hline Firm Size & $\begin{array}{l}0.514 * \\
(0.025)\end{array}$ & $\begin{array}{l}0.517 * \\
(0.036)\end{array}$ & 1.672 & 1.677 \\
\hline Share Female & $\begin{array}{l}0.507 * \\
(0.023)\end{array}$ & $\begin{array}{l}1.684 * \\
(0.037)\end{array}$ & 1.660 & 5.387 \\
\hline Share older & $\begin{array}{l}0.054 * \\
(0.020)\end{array}$ & $\begin{array}{l}0.182 * \\
(0.031)\end{array}$ & 1.055 & 1.200 \\
\hline Share younger & $\begin{array}{l}-0.009 \\
(0.020)\end{array}$ & $\begin{array}{l}0.130 * \\
(0.031)\end{array}$ & 0.991 & 1.139 \\
\hline $\begin{array}{l}\text { Share of Skilled } \\
\text { workers }\end{array}$ & $\begin{array}{c}0.013 \\
(0.020)\end{array}$ & $\begin{array}{l}-0.192 * \\
(0.033)\end{array}$ & 1.013 & 0.825 \\
\hline Weekend & $\begin{array}{l}0.207 * \\
(0.045)\end{array}$ & $\begin{array}{l}0.839 * \\
(0.076)\end{array}$ & 1.230 & 2.314 \\
\hline Night & $\begin{array}{l}-0.007 \\
(0.053)\end{array}$ & $\begin{array}{c}-0.162 * * \\
(0.082)\end{array}$ & 0.993 & 0.850 \\
\hline Shift work & $\begin{array}{l}0.104 * \\
(0.046)\end{array}$ & $\begin{array}{c}0.109 \\
(0.071)\end{array}$ & 1.110 & 1.115 \\
\hline $\begin{array}{l}\text { Short term } \\
\text { contracts }\end{array}$ & $\begin{array}{l}0.353^{*} \\
(0.023)\end{array}$ & $\begin{array}{l}0.197 * \\
(0.038)\end{array}$ & 1.423 & 1.218 \\
\hline $\begin{array}{l}\text { Short term } \\
\text { variation of } \\
\text { activity }\end{array}$ & $\begin{array}{l}-0.115^{*} \\
(0.047)\end{array}$ & $\begin{array}{l}-0.062 \\
(0.070)\end{array}$ & 0.891 & 0.940 \\
\hline $\begin{array}{l}\text { Seasonal variation } \\
\text { of activity }\end{array}$ & $\begin{array}{l}0.099 * * \\
(0.044)\end{array}$ & $\begin{array}{c}0.093 \\
(0.067)\end{array}$ & 1.104 & 1.097 \\
\hline Absenteeism & $\begin{array}{c}0.086 \\
(0.051)\end{array}$ & $\begin{array}{c}0.107 \\
(0.077)\end{array}$ & 1.090 & 1.113 \\
\hline Overtime & $\begin{array}{l}-0.013 \\
(0.042)\end{array}$ & $\begin{array}{l}-0.247 * \\
(0.067)\end{array}$ & 0.987 & 0.781 \\
\hline $\begin{array}{l}\text { Deviance } \\
\text { (MCMC) }\end{array}$ & \multicolumn{4}{|c|}{28711.6} \\
\hline
\end{tabular}

The standard errors are in parentheses.

*** Statistically significant at the 0.10 level, ** significant at the 0.05 level * significant at the 0.01 level 


\section{Appendix: Tables}

Table A1: Descriptive statistics

\begin{tabular}{|c|c|c|c|c|c|}
\hline Covariates & $\mathrm{N}$ & Minimum & Maximum & Mean & $\begin{array}{c}\text { Std. } \\
\text { Deviation }\end{array}$ \\
\hline $\begin{array}{l}\text { Size of the } \\
\text { firm * }\end{array}$ & 19940 & $-0,66$ & 2,49 & 0 & 1 \\
\hline Share Female & 19940 & $-1,40$ & 2,04 & 0 & 1 \\
\hline Share older & 19940 & $-1,19$ & 4,40 & 0 & 1 \\
\hline $\begin{array}{l}\text { Share } \\
\text { younger }(<30 \\
\text { years }\end{array}$ & 19940 & $-1,37$ & 3,43 & 0 & 1 \\
\hline $\begin{array}{l}\text { Share of } \\
\text { skilled } \\
\text { workers }(>50 \\
\text { years }\end{array}$ & 19940 & $-1,61$ & 1,22 & 0 & 1 \\
\hline $\begin{array}{l}\text { Short term } \\
\text { contracts }\end{array}$ & 19940 & 0 & 3,00 & 1,1791 & 0,87533 \\
\hline Weekend & 19940 & 0 & 1,00 & 0,4151 & 0,49275 \\
\hline Night & 19940 & 0 & 1,00 & 0,2932 & 0,45523 \\
\hline Shift work & 19940 & 0 & 1,00 & 0,2986 & 0,45768 \\
\hline $\begin{array}{l}\text { Short term } \\
\text { variation of } \\
\text { activity }\end{array}$ & 19940 & 0 & 1,00 & 0,2358 & 0,42448 \\
\hline $\begin{array}{l}\text { Seasonal } \\
\text { variation of } \\
\text { activity }\end{array}$ & 19940 & 0 & 1,00 & 0,3075 & 0,46146 \\
\hline Overtime & 19940 & 0 & 1,00 & 0,4454 & 0,49703 \\
\hline Absenteeism & 19940 & 0 & 1,00 & 0,1875 & 0,39029 \\
\hline
\end{tabular}

* Number of employees

Number of establishment:19940, number of sectors: 13 NACE C to NACE O and number of Countries 21 .

Source: ESWT (2004-2005) and own calculations. 
Table A2: Random effect: Variance-Covariance Matrix

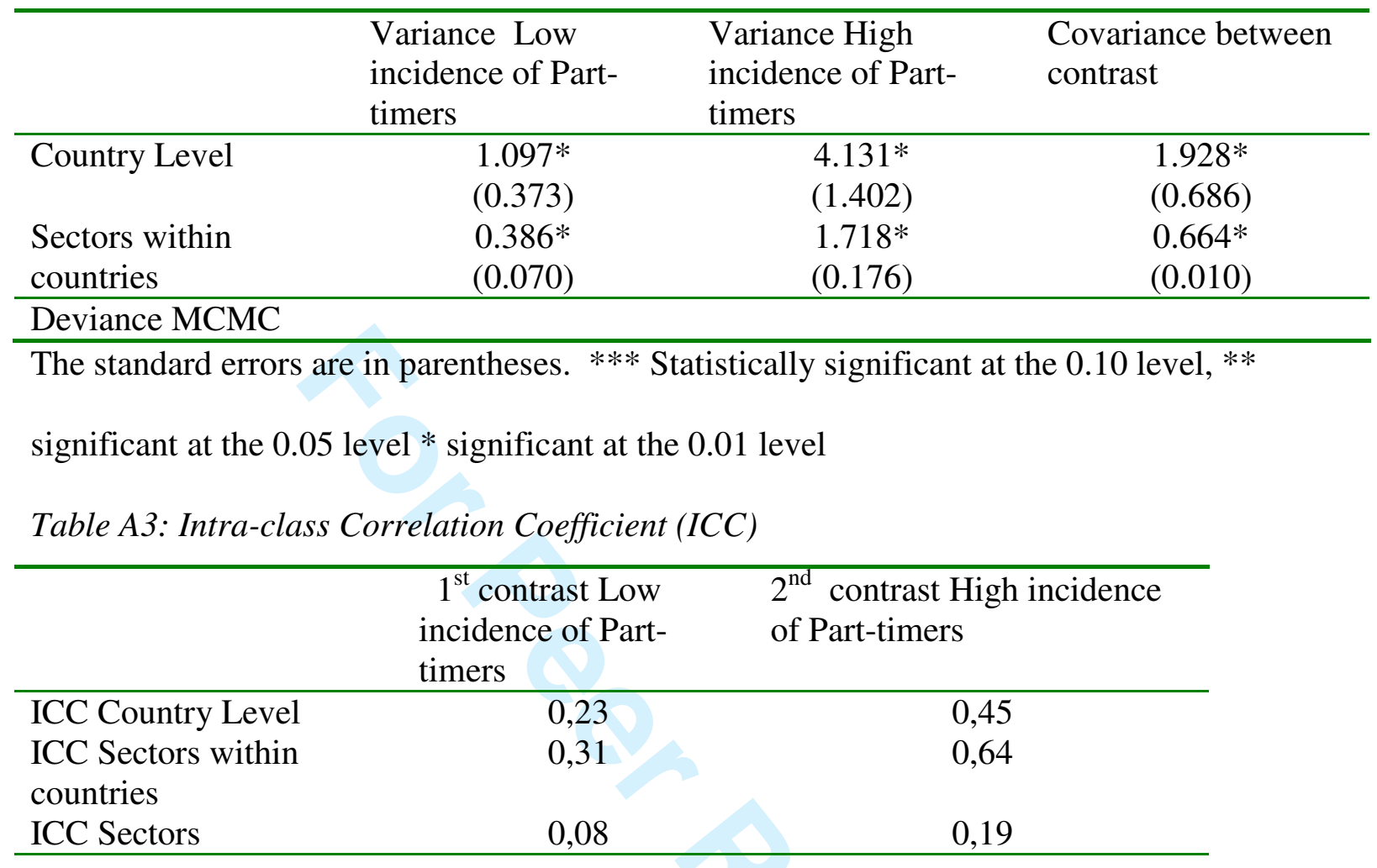

Calculated from equation (4) 
Table A4. Variation of the probability (in percent) due to a variation of one standard deviation (continuous variable) and from 0 to 1 for the dummy variables.

\begin{tabular}{lcc}
\hline Covariates & $\begin{array}{l}\text { First contrast. Low } \\
\text { incidence of Part-timers. } \\
(\%)\end{array}$ & $\begin{array}{c}\text { Second contrast. } \\
\text { High incidence of } \\
\text { Part-timers. (\%) }\end{array}$ \\
Size & 24,0 & 27,8 \\
Female & 7,1 & 78,1 \\
Share older & 1,8 & 9,8 \\
Share younger & $\mathrm{ns}$ & 7,0 \\
Skill level & $\mathrm{ns}$ & $-10,2$ \\
Weekend & 4,3 & 44,0 \\
Night & $\mathrm{ns}$ & $-8,6$ \\
Shift & 5,0 & $\mathrm{~ns}$ \\
Short term contracts & 17,9 & 10,7 \\
Short term variation of & $-5,8$ & $\mathrm{~ns}$ \\
activity & & $\mathrm{ns}$ \\
Seasonal variation of & 4,8 & 5,8 \\
activity & & $-13,1$ \\
Absenteeism & 4,0 & \\
Overtime & $\mathrm{ns}$ & \\
\hline
\end{tabular}

ns: non-significant at conventional level 